\title{
Kevin Corrigan
}

Reason, Faith and Otherness in Neoplatonic and Early Christian Thought.

Farnham, Surrey, Ashgate Publishing, 2013. P P. xii + $298 £ 85$.

The tone of this collection is misleadingly given in the first essay, in which Kevin Corrigan challenges the reader to overcome the gap between secular rationality and religious sensibility by adopting a "perspective beyond each, but present to each, which is capable of including and transforming both" (I, 70). My reaction on reading this was that it wouldn't work, as each group rushed to defend its embattled citadel. Happily, the other essays do in practice what may in fact work, asking each group not to go beyond its perspective, but rather to plumb more deeply the complexity and ambiguity within it. For the believer this is the recognition that faith constitutively contains a moment or aspect of doubt, while for the secularist it is recognizing the unproved, and unprovable, assumptions behind every system of human thought. As Corrigan's autobiographical comments indicate, the believer in our society is more or less forced to do this, and his plea, as I see it, is for the secularist to do the same voluntarily, given that there is no external pressure to do so.

Essays XIII and XVI are the two most explicitly concerned with this split in the modern psyche and do so by questioning the recent, dominant, interpretation that philosophy began as "the substitution of rational explanations and argued theories for myths and religious figures of speech" (XIII, 78) or as "fixated on 'reason' and practiced by a rational elite" (XVI, 1), with the Socratic elenchus as the fine-honed weapon of mass destruction for the irrational in all its varieties. Corrigan argues that this is a misreading of the overwhelming presence of what we would call religious themes in the Greek philosophical tradition in general and Platonism in particular. He highlights two things, firstly, that philosophy is not a substitution but "a radical form of rethinking the diverse modes of its own past" (XVI, 2), especially of drama, poetry, prayer and rituals, and, secondly, that "the birth of philosophy is the meeting place of mythos and logos where the transformation of being and consciousness takes place in the mutual address of the human and divine" (xIII, 79). The rethinking captures the role of philosophy, especially in Plato, of bringing about a new kind of self-reflection to human thinking that transforms these traditional modes of thought and consciousness with a precision that uncovers an underlying human need and limitation that the solidity of traditional wisdom seemed to belie. This is then illustrated in the trajectory of Greek philosophy from Parmenides and Empedocles at the beginning, through Plato, Aristotle, and the Neoplatonists, to Augustine and Anselm in the Christian tradition. His conclusion highlights the tentative and dialogical character of human thought 
and the way the orientation toward the divine "beyond" gives rise to what Corrigan aptly calls "weird questions" (XVI, 13), the perennial philosophical questions that begin with and lead to wonder.

For the second path, the meeting of mythos and logos, Corrigan considers narrative in Essays III, VI, and XV. He shows, in Essay III, how the understanding of the novel in Bakhtin's theory as self-consciously dialogical and self-differentiating from other genres actually captures Plato's authorial role in the Symposium. The Platonic framing surfaces the same kind of differentiation of genres, where each frame calls itself into existence by calling its very existence into question. The structure of recording an event in speech and then by written account reveal the tension and interaction of different genres. Apollodorus' written account is twice removed compared to the eyewitness account of Aristodemus, with various methods of verifying and checking to insure an elusive accuracy. It strikes me that Corrigan's thesis has further support in the elaborately awkward use of the Greek indirect discourse, which confronts the reader constantly with the difference between the two kinds of account. He returns in Essay XV to another Russian, Dostoevsky, to add a link between Plotinus' account of matter as evil and Ivan's devil in The Brothers Karamazov. Corrigan shows how the multifaceted Plotinian analysis of the unreality of evil provides an insight into the rather ambiguous characterization of Ivan's half delirious experience of a rather lackluster modern day devil. The point is the malleability of the Platonic tradition to narrative modes and expression. Essay VI, on the contrary, examines another kind of narrative, of the lives of two female saints, Syncletica and Macrina, by Athanasius and Gregory of Nyssa respectively, and how these narratives reveal and conceal the social force and originality of the two women, themes that recur in other essays as well.

The remaining essays provide examples of themes that dominated ancient and medieval thought and how philosophers within the different religious traditions grappled with them, sharing a common vocabulary but with different paradigms that yielded strikingly different insights. Corrigan concentrates on discussions of the soul, the self, and topics of a more metaphysical character. He begins in Essay II with the history and development of the relation soul and body from Homer through Neoplatonism, setting the stage for the particular issues examined elsewhere. Essay X, XI and XIV, attempt to show, for both Plato and Aristotle and their successors, that the images and analogies used to explain the relation of soul and body strive to capture their integral unity without becoming materially reductionist or transcendentally separatist. Essay XI does this in terms of the soul as harmony, moving from an initial identification of harmony with the arrangement of parts to an ever more sophisticated account of the interaction of corporeal and psychic factors as 
this musical image is exploited with careful analysis, culminating in Gregory of Nyssa's radically concrete and anatomically precise account of the working together of the whole body, brain, nerves and organs transformed by the soul's noetic presence. Essay XIV, for its part, confronts the accepted opposition between the Platonic and Aristotelian accounts of soul as separate or as entelechy, and argues that each position contains an intricate attempt at an integral synthesis. Essay $\mathrm{x}$ uses this enriched understanding of the philosophical background, including Stoic elements, to argue for a greater coherence and subtlety in Augustine's understanding of the soul, with the added impetus of the penetrating reflection of the desert Fathers on their experiences, precisely as interactions of soul and body.

The discussion of the soul is not far from that of the self, but they are not quite the same. In Essay v, Corrigan examines the Plotinian phrase, "alone to the alone," to signal a different sense of self as well as a correction of the misconception that Plotinian and derivative mysticism is narcissistic. He points out that "alone" does not mean isolated, which results instead from the soul's being absorbed by its image in the body, but rather "self-gathered," when the soul finds its own nature in a process of unification that brings it to the One (v, 32-33). The self is thus identified not with soul, nor with intellect, but with that unity that has its source in the One. Essay VII argues that in Plotinus and Gregory of Nyssa the opposition between Platonic dualism and Aristotelian entelechism is overcome through a sense of personal identity that is multidimensional, but with its roots in the unique unity of God and, for Gregory, in the radical equality of soul and body (VII, 63). Finally, Essay IX explores this insight in a retrieval of Augustine's account of love of God, of the self, and of one's neighbor. "Usus" thus relates to a love of others (and oneself) that is mediated and provisional, while "frui" indicates a love of the other for its own sake (IX, 101-102). This proper kind of love, like Plotinus' self-gathered unity, is rooted in the relation of oneself and other things to God.

Corrigan begins in Essay IV with a look at contemplation and creative making in Plotinus, which have been interpreted in extrinsic and static modes that obliterate both any sense of real privacy and individual causal contribution; only the Intellect or Demiurge is active (IV, 6-8). Instead, we have a dynamic system in which the parts play as active a role as their individual nature allows. I would add that Corrigan's analysis of III.8[30] has support in other treatises, especially IV.4[28].30-45, presenting the sympathetic unity of the cosmos. Essay VIII shows how the use of ousia and hypostasis in the Cappadocians derives from the Neoplatonic "hypostases," but does so "by restoring them to the only places their logic warranted: that is, in individuals" (VIII, 134). Finally, the critique of metaphor in Nietzsche and Derrida finds a reply in the light 
metaphysics of Plotinus and Thomas Aquinas. Intelligible light has a proper meaning and is not merely metaphorical, siding with Beierwaltes rather than Ferwerda (XII, 189-190). Restricting my comments to his analysis of Plotinus, Corrigan shows that this is rooted in the nature of light as activity, especially as developed in IV.5[29].7. A more careful reading of the text supports his position even more, since he does not fully see that Plotinus is not merely modifying the role of the Aristotelian transparent medium, but is eliminating it altogether, making even visible light as pure an activity as one can have, given that it is from one body and appears in another. Dynamic activity is the analogical bridge that both Plotinus and Aquinas use to move from sensible to intelligible modes of operation.

This does not picture the origins of philosophy as a crabbed intellectualism, but as engaged with mythos as well as logos, with religion as well as science. Christian thinkers in antiquity and the middle ages similarly rethink their own tradition, both religious and philosophical, and in the process articulate some of the ideas we hold most dear, personal freedom and dignity, with the enduring value of relationships and their memories that the Greeks exhort us to discard.

Gary M. Gurtler S.J.

Boston College

gurtlerg@bc.edu 